CAHRS at Cornell University 187 Ives Hall

Cornell University

School of Industrial and Labor Relations

Ithaca, NY 14853-3901 USA

Tel. 607 255-9358

Center for Advanced Human Resource Studies

www.ilr.cornell.edu/CAHRS

Worhing Paper gealeg

\title{
Strategic Management and HRM
}

\author{
Mathew R. Allen \\ Patrick M. Wright
}

Working Paper 06 - 04 


\title{
Strategic Management and HRM
}

\author{
Mathew R. Allen
}

Patrick M. Wright

Department of Human Resource Studies

School of Industrial and Labor Relations

Cornell University

Ithaca, NY 14853-3901

April 2006

http://www.ilr.cornell.edu/cahrs

This paper has not undergone formal review or approval of the faculty of the ILR School. It is intended to make results of Center research available to others interested in preliminary form to encourage discussion and suggestions.

Most (if not all) of the CAHRS Working Papers are available for reading at the Catherwood Library. For information on what's available link to the Cornell Library Catalog:

http://catalog.library.cornell.edu if you wish. 
Abstract 


\section{Strategic Management and HRM}

\section{Introduction}

It has been said that the most important assets of any business walk out the door at the end of each day. Indeed, people and the management of people are increasingly seen as key elements of competitive advantage (Boxall \& Purcell, 2003; Pfeffer, 1998; Gratton, Hailey \& Truss, 2000). Spurred on by increasing competition, fast paced technological change, globalization and other factors, businesses are seeking to understand how one of the last truly competitive resources, their human resources, can be managed for competitive advantage.

This idea that the human resources of a firm can play a strategic role in the success of an organization has led to the formation of a field of research often referred to as strategic human resource management (SHRM). This relatively young field represents an intersection of the strategic management and human resource management (HRM) literatures (Boxall, 1998; Boxall and Purcell, 2000). Wright and McMahan (1992) defined strategic human resource management as "the pattern of planned human resource deployments and activities intended to enable the firm to achieve its goals" (1992, p. 298).

The purpose of this chapter is to discuss this intersection between Strategic Management and HRM, what we know, and future directions for SHRM research. We will begin by briefly discussing the concept of strategy and the popularization of the resource-based view (RBV) of the firm. Next we will address its role in creating the link between HRM and Strategic Management including key questions that the RBV has raised in relation to SHRM. We will then examine the current state of affairs in SHRM; the progress made, and key questions and concerns occupying the attention of SHRM researchers. Finally, we will conclude with our views on future directions for SHRM research.

\section{Strategy And The Resource-Based View Of The Firm}

The field of strategy focuses on how firms can position themselves to compete, and its popularity began increasing exponentially in the mid 1980s with two books. First, Peters \& 
Waterman's (1982) In Search of Excellence provided a practitioner-oriented analysis of excellent companies and the common threads that united them. However, Porter's (1980) Competitive Strategy presented a more academically based analysis of strategy, but in a way that practitioners/executives quickly gravitated toward. This Industrial/Organization Economicsbased analysis primarily focused on industry characteristics, in particular the five forces of barriers to entry, power of buyers, power of suppliers, substitutes, and competitive rivalry as the determinants of industry profitability. While this analysis did propose four generic strategies (cost, differentiation, focus, and 'stuck in the middle'), the bulk of the analysis focused on external factors that determined company profitability. This framework seemed to dominate strategic management thinking of the early 1980 s.

However, with the advent of the resource-based view of the firm (Barney, 1991; Wernerfelt, 1980), strategic management research moved to a more internal focus. Rather than simply developing competitive strategies to address the environment, the resource-based view suggested that firms should look inward to their resources, both physical and intellectual, for sources of competitive advantage. Though others had addressed the concept of the RBV previously, Barney (1991) specifically explicated how firm resources contribute to the sustained competitive advantage of the firm. He suggested that resources that are valuable, rare, inimitable and non-substitutable will lead to competitive advantage.

Value in this context is defined as resources either exploiting opportunities or neutralizing threats to the organization and rarity is defined as being a resource that is not currently available to a large number of the organization's current or future competitors (Barney, 1991). Inimitability refers to the fact it is difficult for other firms to copy or otherwise reproduce the resources for their own use. Finally, non-substitutability means that other resources cannot be used by competitors in order to replicate the benefit (Barney 1991). When all four of these conditions are met, it is said that the firm or organization possess resources which can potentially lead to a sustained competitive advantage over time. 
The resource-based view has become almost the assumed paradigm within strategic management research (Barney and Wright, 2001). It has been the basic theoretical foundation from which much of the current strategic management research regarding knowledge-based views of the firm (Grant, 1996), human capital (Hitt et al., 2001), and dynamic capabilities (Teece, Pisano, \& Schuen, 1997) are derived. In fact, Priem and Butler (2001) mapped RBV studies against eighteen strategy research topics, demonstrating the breadth of its diffusion within the strategic management domain. More importantly from the standpoint of this chapter, the resource-based view has become the guiding paradigm on which virtually all strategic HRM research is based (Wright, Dunford, \& Snell, 2001).

In spite of the wide acceptance of the RBV, it is not without criticism. Priem and Butler, $(2001 \mathrm{a}, \mathrm{b})$ have leveled the most cogent critique to date suggesting that the RBV does not truly constitute a theory. Their argument focuses primarily on two basic issues. First, they suggest that the RBV is basically tautological in its definition of key constructs. They note that Barney's statement that "if a firm's valuable resources are absolutely unique among a set of competing and potentially competing firms, those resources will generate at least a competitive advantage (Barney, 2001: 102)" essentially requires definitional dependence. In other words, without definitional dependence (i.e. "valuable resources") the diametrical statement - that unique firms possess competitive advantages - does not logically follow.

Their second major criticism of the RBV as a "theory" focuses on the inability to test it (Priem \& Butler, 2001b). They note the necessity condition of "falsifiability" for a theory. In other words, in order for a set of stated relationships to constitute a theory, the relationships must be able to be measured and tested in a way that allows for the theory to be found to be false. This relates directly to the tautology criticism, but brings the debate into the empirical realm.

In spite of these criticisms, even the critics agree that the impact of the RBV on strategic management research has been significant and that the effort to focus on the internal aspects of the organization in explaining competitive advantage has been a useful one (Preim \& Butler, 
2001b). While the debate might continue as to the theoretical implications of the RBV for strategic management research, it is clear that it has made a significant contribution to Strategic Management and, more specifically, SHRM research (Wright, Dunford \& Snell, 2001).

\section{A Brief History Of Strategic HRM}

Wright and McMahan's (1992) definition of strategic human resource management illustrates that the major focus of the field should be on aligning HR with firm strategies. Jim Walker's (1980) classic book, Human Resource Planning, was one of the first to directly suggest considering a firm's business strategy when developing a human resource plan. Devanna, Fombrum, and Tichy's (1981) article, "Human Resources Management: a Strategic Perspective", added to the foundation. These attempts tended to take an existing strategy typology (e.g. Miles and Snow's (1978) prospectors, analyzers and defenders) and delineate the kinds of HRM practices that should be associated with each strategy. These attempts to tie HRM to strategy have been referred to as "vertical alignment" (Wright \& McMahan, 1992).

Beer, Spector, Lawrence, Mills and Walton (1984) introduced an alternative to the individual HR sub-function framework for HR strategy. They argued that viewing HRM as separate HR sub-functions was a product of the historical development of HRM and current views of HR departments. They proposed a more generalist approach to viewing HRM with the focus on the entire HR system rather than single HR practices. This led to a focus on how the different HR sub-functions could be aligned and work together to accomplish the goals of HRM and a more macro view of HRM as whole rather than individual functions. This alignment of HR functions with each other is often referred to as "horizontal alignment" (see this Handbook, chapter 19.)

The combination of both vertical and horizontal alignment was a significant step in explaining how HRM could contribute to the accomplishment of strategic goals. However, given the external focus of the strategic management literature at that time, HR was seen to play only a secondary role in the accomplishment of strategy with an emphasis on the role that HRM 
played in strategy implementation, but not strategy formulation. Lengnick-Hall and LengnickHall (1988) stated "strategic human resource management models emphasize implementation over strategy formulation. Human resources are considered means, not part of generating or selecting strategic objectives. Rarely are human resources seen as a strategic capacity from which competitive choices should be derived" (1988, p.456). A shift in strategic management thinking would be required to change that perception and open the door for further development of the SHRM literature.

The diffusion of the resource-based view into the Strategic HRM literature spurred this paradigmatic shift in the view of the link between strategy and HRM. Because the resourcebased view proposes that firm competitive advantage comes from the internal resources that it possesses (Wernerfelt, 1984; Barney, 1991), the RBV provided a legitimate foundation upon which HRM researchers could argue that people and the human resources of a firm could in fact contribute to firm-level performance and influence strategy formulation.

This resulted in a number of efforts to conceptually or theoretically tie strategic HRM to the resource-based view. For instance, Wright, McMahan, and McWilliams (1994) suggested that while HR practices might be easily imitated, the human capital pool of an organization might constitute a source of sustainable competitive advantage. Lado and Wilson (1994) argued that HR practices combined into an overall HR system can be valuable, unique, and difficult to imitate, thus constituting a resource meeting the conditions necessary for sustained competitive advantage. Boxall $(1996,1998)$ proposed a distinction between human resource advantage (advantage stemming from a superior human capital pool) and organizational process advantage (advantage stemming from superior processes for managing human capital).

The resource-based view also provided the theoretical rationale for empirical studies of how HR practices might impact firm success. One of the early empirical studies of this relationship was carried out by Arthur (1994). Using a sample of steel mini-mills, he found that a specific set of HR practices was significantly related to firm performance in the form of lower 
scrap rates and lower turnover. Huselid (1995), in his landmark study, demonstrated that the use of a set of 13 HRM practices representing a 'high-performance work system' was significantly and positively related to lower turnover, and higher profits, sales, and market value for the firms studied. In a similar study, MacDuffie (1995), using data from automobile manufacturing plants, demonstrated that different bundles of HR practices led to higher performance, furthering the argument that the integrated HR system, rather than individual HR practices, leads to higher performance. Delery and Doty (1996) similarly demonstrated the impact of HR practices on firm performance among a sample of banks.

This vein of research quickly expanded in the U.S. (e.g., Batt, 1999; Huselid, Jackson, \& Schuler, 1996; Youndt, Snell, Dean, \& Lepak,, 1996), the U.K. (e.g., Brewster, 1999; Guest, 1997; Guest, Michie, Conway, \& Sheehan, 2003; Tyson, 1997), elsewhere in Europe (e.g., d'Arcimoles, 1997; Lahteenmaki, Story, \& Vanhala, 1998; Rodriguez \& Ventura, 2003) and Asia (e.g., Bae \& Lawler, 2000; Lee \& Chee, 1996; Lee \& Miller, 1999), as well as in multinational corporations operating in multiple international environments (Brewster, Sparrow, and Harris, 2000).

In sum, the RBV, with its focus on the internal resources possessed by a firm, has given the field a theoretical understanding of why human resources systems might lead to sustainable competitive advantage and provided the spark to generate empirical research in this vein (Guest, 2001; Paauwe \& Boselie, 2005; , Wright et al, 2005).

\section{Key Questions Raised By The Application Of RBV To SHRM}

In spite of the significant amount of research demonstrating a link between HRM practices and firm performance, there are several key questions regarding the RBV and its implications for SHRM research that remain unanswered. First, there is some question as to whether current research on HRM and performance is truly testing the RBV. Second, there is still a general lack of understanding around the concept of fit, and its role in the link between strategy and HRM. Third, there are still unanswered questions regarding HRM and whether or 
not HRM defined as systems of HR practices truly constitutes a resource under the conditions outlined by Barney (1991) and, specifically, whether those resources are truly sustainable over time. Finally, there are several measurement and methodological issues that, while not within the direct scope of this chapter, are worth mentioning as they are pertinent to our discussion of this intersection between Strategic Management and HRM research.

\section{Testing of the RBV within SHRM}

While the SHRM research just discussed has used the RBV as a basis for the assertion that HRM contributes to performance, it has not actually tested the theory that was presented in Barney's (1991) article (Wright, Dunford \& Snell, 2001). Most of this research has taken a similar view on how HR practices can lead to firm performance. The model generally argues that HRM in the form of HR practices directly impacts the employees either by increasing human capital or motivation or both. This in turn will have an impact on operational outcomes such as quality, customer service, turnover or other operational level outcomes. These operational outcomes will in turn impact firm-level outcomes such as financial performance in the form of revenues, profits or other firm-level measures of performance (Dyer, 1984).

In a similar vein, Wright Dunford and Snell, (2001) point out that there are three important components of HRM that constitute a resource for the firm that are influenced by the HR practices or HR system. First, there is the human capital pool comprised of the stock of employee knowledge, skills, motivation and behaviors. HR practices can help build the knowledge and skill base as well as elicit relevant behavior.

Second, there is the flow of human capital through the firm. This reflects the movement of people (with their individual knowledge, skills and abilities) as well as knowledge itself. HR practices can certainly influence the movement of people. However, more importantly, the types of reward systems, culture, and other aspects of HRM influence the extent to which employees are willing to create, share, and apply knowledge internally. 
Third, the dynamic processes through which organizations change and/or renew themselves constitute the third area illustrating the link between HRM and the resource-based view of the firm. HR practices are the primary levers through which the firm can change the pool of human capital as well as attempt to change the employee behaviors that lead to organizational success.

There appears to be a general consensus among SHRM researchers around the general model of the HR to performance relationship and the role of HR practices, the human capital pool, and employee motivation and behaviors as discussed by Dyer (1984) and others. The implications of this for RBV and SHRM research is that while separate components of the full HRM to performance model have been tested such as HR practices (Huselid, 1995; McDuffie, 1995) and human capital (Richard, 2001; Wright, McMahan \& Smart, 1995), a full test of the causal model through which HRM impacts performance has not (Wright, Gardner, Moynihan, \& Allen, 2005; Wright, Dunford \& Snell, 2001; Boxall, 1998). Current research has established an empirical relationship between HR practices and firm performance, but more remains to be done. By testing the full model, including the additional components of the human capital pool and employee relationships and behaviors, a more complete test of the underlying assumptions of the RBV could be established, thus adding credibility to the theoretical model of the relationship between HRM and performance.

\section{Fit and the Resource-based View of the Firm}

In the Priem and Butler (2001) critique of the RBV, one of the points brought up as a theoretical weakness of the RBV is lack of definition around the boundaries or contexts in which it will hold. They point out that "relative to other strategy theories ... little effort to establish the appropriate contexts for the RBV has been apparent" (2001 p. 32). The notion of context has been an important issue in the study of SHRM (Delery \& Doty, 1996, Boxall \& Purcell, 2000). Most often referred to as contingencies (or the idea of fit), contextual arguments center on the 
idea that the role that HRM plays in firm performance is contingent on some other variable. We break our discussion of fit into the role of human capital and HR practices.

Human Capital and Fit. The most often cited perspective for explaining contingency relationships in SHRM is the behavioral perspective (Jackson, Schuler \& Rivero, 1989) which posits that different firm strategies (other contingencies could be inserted as well) require different kinds of behaviors from employees. Consequently, the success of these strategies is dependent at least in part on the ability of the firm to elicit these behaviors from its employees (Cappelli \& Singh, 1992; Wright \& Snell, 1998).

Going back to the distinction between human capital skills and employee behavior, Wright and Snell (1999) noted that skills and abilities tend to be necessary, but not sufficient conditions for employee behavior. Consequently, any fit to firm strategy must first consider the kinds of employee behavior (e.g., experimentation and discovery) required to successfully execute the strategy (e.g., focused on offering innovative products), and the kinds of skills necessary to exhibit those behaviors (e.g., scientific knowledge). Obviously, the workforce at Nordstrom's (an upscale retailer) is quite different from the workforce at Wal-Mart (a discount retailer). Thus, the resource-based application to SHRM requires focusing on a fit between the skills and behaviors of employees that are best suited to the firm's strategy (Wright et al. 1995).

While this idea of fit focuses on across-firm variance in the workforce, Lepak and Snell (1999) developed a framework that simultaneously addresses variation across firms and variations in HR systems within firms (see this Handbook, chapter 11). Their model of 'human resource architecture' posits that the skills of individuals or jobs within a firm can be placed along two dimensions: value (to the firm's strategy) and uniqueness. Their framework demonstrates how different jobs within firms may need to be managed differently, but it also helps to explain differences across firms. For instance, within Wal-Mart, those in charge of logistics have extremely valuable and unique skills, much more so than the average sales 
associate. On the other hand, at Nordstrom's, because customer service is important, sales associate skills are more critical to the strategy than those of the logistics employees.

HR Practices and Fit. The theoretical assumption that the skills and behaviors of employees must fit the strategic needs of the firm in order for the workforce to be a source of competitive advantage leads to the exploration of how HR practices might also need to achieve some form of fit. With regard to vertical fit, as noted previously, business strategies require different skills and behaviors from employees. Because HR practices are generally the levers through which the firm manages these different skills and behaviors, one would expect to see different practices associated with different strategies. For instance, one would expect that firms focused on low cost might not pay the same level of wages and benefits as firms focused on innovation or customer service.

Horizontal fit refers to a fit between HR practices to ensure that the individual HR practices are set up in such a way that they support each other (Boxall \& Purcell, 2003; Baird \& Meshoulam, 1988, Delery, 1998). An example of this would be a selection process that focuses on finding team players and a compensation system that focuses on team-based rewards. Theoretically, the rationale for horizontal fit suggests that (a) complementary bundles of HR practices can be redundantly reinforcing the development of certain skills and behaviors resulting in a higher likelihood that they will occur and (b) conflicting practices can send mixed signals to employees regarding necessary skills and behaviors that reduce the probability that they will be exhibited (Becker \& Huselid, 1998). There appears to be some agreement in the literature that both types of fit are necessary for optimal impact of HRM on performance (Baird \& Meshoulam, 1988; Delery, 1998; Delery \& Doty, 1996; Boxall \& Purcell, 2003), but not necessarily empirical support for these types of fit (see this Handbook, chapter 27; Wright \& Sherman, 1999).

Potential Pitfalls of Fit. The idea of fit, whether it be vertical or horizontal, raises two important questions for SHRM researchers. The first question focuses on empirical support for 
the idea of fit. Second, even if fit has positive consequences in the short term, does fitting HRM practices with strategy or other contingent variables universally lead to positive results? That is, are there negative implications of fit?

As previously discussed, numerous researchers have argued for fitting HRM to contingent variables. However, the efficacy of fit has not received much empirical support (Paauwe, 2004; Wright \& Sherman, 1999). Huselid's (1995) landmark study sought to test the fit hypothesis using a variety of conceptualizations of fit, yet found little support. Similarly, Delery and Doty (1996) only found limited support across a number of fit tests. The lack of empirical support may largely be due to focusing only on a fit between generic HRM practices and strategy, rather than the outcomes, or products (Wright, 1998) of the HRM practices (skills, behaviors, etc.). Thus, it seems that it may be too early to draw any definite conclusions about the validity of the fit hypothesis.

However, while fit between HRM practices and various contingency variables might enhance the ability of HRM to contribute to firm performance, there is also the possibility that a tight fit between HRM and strategy may inhibit the ability of the firm to remain flexible enough to adapt to changing circumstances. Firms are increasingly required to adapt to environments that are constantly changing, both within and outside the firm. A tight fit may appear to be desirable but during times of transition and/or change a lack of fit might make adaptation and change more efficient (Lengnick-Hall, Lengnick-Hall, 1988). Wright and Snell (1998) developed a framework in which HRM contributes to fit and flexibility simultaneously without conflict between the two, but this framework has yet to be tested and the question remains as to when and where fit might be more or less appropriate.

The second question raised by contextual issues surrounding SHRM and the idea of fit is related to the efficacy of fit. Regardless of whether or not fit can have a positive effect on organizational outcomes, there is still some question as to whether or not true fit with key contingencies is feasible. Large organizations operate in complex environments, often across 
multiple products, industries and geographies. This complexity leads to questions regarding the ability of the firm to fit HRM practices to all of these diverse and complex circumstances (Boxall \& Purcell, 2003).

In addition, Boxall and Purcell, (2003) argue that there are competing ideals within a business that require trade-offs in fit. They describe fit as "a process that involves some tension among competing objectives in management and inevitably implies tensions among competing interests" (2003, p. 188). A simple example of these tensions can be seen in attempting to fit a strategy of commitment to employees with a hostile or extremely competitive operating environment. A firm with a strategic commitment to the well-being of employees operating in an economic downturn or time of increased competition may be forced to make choices between commitment to employees and a need for restructuring, layoffs or other non-friendly actions toward employees in order to stay solvent. In these situations, compromises will have to be made on either the fit with the strategy or the fit with the environment or both, raising the question again as to whether or not a true fit with contingencies is feasible.

These questions regarding the ability to achieve fit and the desirability of achieving fit do not diminish the importance of understanding contextual issues in SHRM research.

Understanding the contextual issues surrounding HRM and its impact on performance remains critical. In spite of the interest in the role of contextual issues and fit in SHRM, findings in support of contingency relationships have been mixed (Wright \& Sherman, 1999). Much of this criticism could be due to ineffective methods used in the measurement of HRM or the contingency and performance variables studied or that the correct contingencies have not yet been studied (Becker \& Gerhart, 1996, Rogers \& Wright, 1998; Wright \& Sherman, 1999). In addition, Boxall and Purcell (2000) have argued that more complex and comprehensive models of contingency relationships are needed in order to understand the impact of context on the HRM to performance relationship. Regardless of the reasoning, it is clear that the impact of context on this important relationship is not yet completely understood and more research is 
needed to understand the role of context, as well as questions surrounding models of fit in SHRM research.

\section{HRM Practices and Sustainable Competitive Advantage}

Another issue that has been raised by the RBV and its application to SHRM research is the sustainability of HRM as a competitive advantage. Whether one focuses on bundles of HR practices as an HR system, the human capital pool or employee relationships and behaviors, there remains the question as to whether HRM as a resource meets the inimitability and nonsubstitutability conditions that are required in the RBV for sustained competitive advantage (Barney, 1991).

According to Barney (1991), there are three general reasons why firm resources would be difficult to imitate: the resources are created and formed under unique historical conditions, the resources are causally ambiguous, or the resources are socially complex.

Labeled as path dependency by Becker and Gerhart (1996), the unique historical conditions under which HRM is formed in individual firms may make its understanding and replication extremely difficult, if not impossible. HR systems are developed over time and the complex history involved in their development makes them difficult to replicate. The development and implementation of a single HR practice such as a variable pay system takes place over time including time to solicit management input and buy-in, work out discrepancies, and align the practice with current strategies as well as firm culture and needs. The end result is a practice that reflects the philosophies and culture of the firm and its management, created to solve the specific needs of the company. Compound that single HR practice with a whole system of practices each with its own history and evolution specific to a particular firm, its philosophies and current situation and you have an HR system that cannot be bought or easily replicated without a significant investment both of time and financial resources.

Causal ambiguity implies that the exact manner in which human resource management contributes to the competitive advantage of the firm is either unknown or sufficiently ambiguous 
so as to be difficult or impossible to imitate. According to Becker and Gerhart (1996), the ability to replicate a successful HR system would require an understanding of how all of the elements of this complex system interact and in turn impact the performance of an organization. Given the previous discussion of the basic HRM to performance model and the manner in which it is expected that HRM contributes to firm performance, it is difficult to imagine how the intricate interplay among various HR practices, human capital and employee behaviors, employee outcomes, operational outcomes and firm-level outcomes could be understood by a competitor in a meaningful way.

Finally, Barney (1991) points out that competitors will find it difficult to replicate a competitive advantage based on complex social phenomena. Given the nature of HRM and its direct relation to employees, almost every aspect of the HR system, the human capital and especially the employee behavior and relationships has a social component. The way in which HR practices are communicated and implemented among different departments and parts of the organization is influenced by the various social relationships involved; top management to general managers, general managers to department heads or managers and those managers to employees as well as interactions between departments and employees. The complexity of the social relationships in the case of HRM makes it difficult for competitors to imitate it.

Finally, for a resource to constitute a source of sustainable competitive advantage it must be non-substitutable. This implies that competitors should not be able to use a different set of resources in order to achieve similar results (Barney, 1991). This concept has not yet been tested, but could provide for interesting research in the area of contextual factors and SHRM.

If, in fact, it is found that a particular set of HR practices is positively related to performance in a given context, then, a follow-on question to that which would get at the substitutability question might be whether or not there is another set of HR practices for which the results are similar. This could lead to discussions about strategic configurations of HR 
practices rather than universal high-performance work systems that have dominated past research (Delery \& Doty, 1996). Regardless of whether there is one or many ways to achieve similar results in different contextual situations, the testing of these possibilities would lead to an increased understanding of the relationship between the RBV and SHRM research and the sustainability of HRM as a strategic resource.

\section{Measurement and Methodological Issues}

In addition to key questions surrounding the RBV and SHRM research, there are also several measurement and methodological issues which have hindered our ability to better understand the relationship between strategy and HRM. Measurement issues relating to the HRM, competitive advantage and key control variables have made the comparison of results across studies and interpretation of findings difficult (Rogers \& Wright, 1998; Dyer \& Reeves, 1995). In addition, there are questions around the appropriate level of analysis within the firm at which to test these relationships as well as issues related to the mixing of variables measured at different levels of analysis (Rogers \& Wright 1998, Becker \& Gerhart, 1996). Finally, as was pointed out, the majority of research to date has focused on the relationship between HR systems and firm-level performance and, while the findings indicate a positive relationship, there is insufficient evidence at this point to be able to infer that the relationship is causal (Wright et al., 2005). A full discussion of these issues is beyond the scope of this chapter and a more thorough discussion may be found in other chapters in this text (see particularly chapters 26 and 27), but it is important to note in discussing key questions in SHRM that they exist and need to be addressed or at least considered in future research.

\section{Future Directions}

Research on SHRM management over the past decade has made significant progress in developing our understanding of the role that HRM plays in firm performance. The field now has a significant foundation upon which to build future research. In our opinion, future research should focus on both answering key questions that remain in understanding the relationship 
between HRM and performance and by expanding or broadening what is considered SHRM. Such extension would encompass both other resources and other theories currently studied in strategic management research.

\section{Key Unanswered Questions}

The previous portion of the chapter pointed out several key questions that have been raised as a result of the application of the RBV to SHRM research that are not yet answered. First, research that directly tests the concepts outlined in the RBV has not been done (Priem \& Butler, 2001). Thus future research should focus on testing the concepts of the RBV by testing the full model through which HRM leads to competitive advantage or firm performance. Do HR practices impact the human capital pool and the relationships and behaviors of the employees and do those outcomes in turn impact both operational and firm-level performance? Answering these questions by testing the full causal model would be a significant contribution to our understanding of the strategic nature of HRM. In essence, this reflects the "black box process" that Priem and Butler (2001) argued must be addressed by RBV theorists and researchers.

Second, future research should focus on understanding the contextual questions surrounding the HRM to performance relationship. Mixed results in past contextual research is not reason enough to abandon the question all together. It is highly likely that HRM matters more or less in certain situations or under certain conditions. Efforts should be made to continue to test established models of HRM in new and unique situations. In addition, more thorough tests of moderating variables in the HRM to performance relationship should be tested. Given the complexity involved in the measurement and testing of these relationships and the mixed results of past research in this area it is likely that researchers will need to seek out contexts with reduced complexity such as departments within large organizations or small businesses where reduced complexity will provide more meaningful measures of potential moderating variables and more meaningful tests of the moderating relationships can be performed. 
Another step that needs to be taken in understanding the role of context in the HRM to performance relationship is to move away from universal-type models of HRM such as highperformance work systems and high-involvement work systems and develop and test different configurations of HR practices that might apply to specific situations. In doing this, researchers will be able to better understand the specific bundles or HR practices that are applicable or fit with different types of organizations or situations, thus making a significant contribution to our understanding of the types of HRM that will matter in a given situation.

\section{Expanding the Role of SHRM}

Future research in SHRM should focus on conceptually expanding what is considered to be the role of SHRM. Historically, SHRM has been viewed as the interface between HRM and strategic management (Boxall, 1996) with the focus of much research being on understanding how the HRM function (namely HRM practices) can be strategically aligned so as to contribute directly to competitive advantage. This implies a concern with how HR practices can contribute to strategy implementation without addressing the larger question of how HRM can contribute or play a role in strategy formulation (Lengnick-Hall \& Lengnick-Hall, 1988).

Wright et. al. (2001) argued that it is the human capital (the knowledge skills and abilities of the human resources) as well as the relationships and motivation of the employees that leads to competitive advantage. The purpose of HR practices is to develop or acquire this human capital and influence the relationships and behaviors of the employees so that they can contribute to the strategic goals of the firm. Future research should examine human capital and the social interactions and motivations of the human element within a firm (Snell, Shadur, \& Wright, 2002), not only as independent variables but also as mediating and dependent variables. A focus in this area will bring the field more in line with contemporary views in strategic management. Research in this area will also help us to get beyond questions regarding how HR practices can facilitate the strategic goals of a firm and begin to understand how organizations can understand the resources found in their human element and use that 
understanding to influence or even drive their decisions about their strategic direction. For instance, IBM's strong HR processes/competencies led it into the business of offering outsourced HR services. This was an internal resource that was extended into a new product line, and illustrates how an understanding of such resources can influence strategic direction.

Along these same lines, another way to break away from this notion of HRM as a facilitator of the strategic direction of the firm is by focusing on some of the resources currently salient to strategic management researchers. In their review of the RBV and SHRM relationship, Wright, Dunford and Snell, (2001) argue that the RBV created a link between HRM and strategic management research and that as a result of this link the two fields were converging. Because of this convergence, the potential impact of SHRM research on mainstream strategy issues is tremendous. Increasingly, strategy researchers are focusing on knowledge and knowledge-based resources (Argote, \& Ingram, 2000; Grant, 1996;), human capital (Hitt et al. 2001), social capital (Inkpen \& Tsang, 2005; McFadyen, Ann, \& Albert, 2004), capabilities (Dutta, Narasimhan, \& Rajiv, 2005), and dynamic capabilities (Teece, Pisano, \& Schuen, 1997), as critical resources that lead to organizational success. While HRM practices strongly influence these resources, the SHRM literature seems almost devoid of empirical attention to them. Only recently have researchers began to explore these issues (Kinnie, Swart, \& Purcell, 2005; Thompson \& Heron, 2005). Additional research in these areas would provide tremendous synergy between HRM and strategy.

In addition, alternative theories such as 'learning organizations' (Fiol \& Lyles, 1985; Fisher \& White, 2000), real options theory (McGrath, 1997; Trigeorgis, 1996) and institutional theory (Meyer \& Rowan, 1977) can be combined with SHRM research to enhance our understanding of the strategic nature of HRM. For instance, Bhattacharya and Wright (2005) showed how real options theory can be applied to understanding flexibility in SHRM. In addition, Paauwe and Boselie (Chapter 9) provide a detailed analysis of how institutional theory can better inform SHRM research. The use of these in addressing questions in SHRM research will 
provide new lenses through which researchers are able to view the HRM to performance relationship, potentially providing new insights and ideas that will further our understanding of SHRM.

\section{Conclusion}

While the field of strategic HRM is relatively young, significant progress has been made at a rapid pace. Researchers have provided great theoretical and empirical advancements in a period of just over 25 years. Much of this progress is the result of the RBV and its emphasis on the internal resources of the firm as a source of sustainable competitive advantage. The RBV and its application to SHRM research created an important link between strategic management and HRM research. Its application has been followed by a significant amount of research using the RBV as a basis for assertions about the strategic nature of HRM.

However, the link between HRM and strategic management can be strengthened by breaking away from the focus on HR practices. Other key resources currently being researched in strategic management have the potential to be directly influenced by HRM, but their coverage by SHRM researchers has been minimal, leaving a tremendous opportunity for future research in this area. In addition to this, new theories relevant to strategic management have yet to be combined with SHRM research, leaving potential for additional contributions to our understanding of the intersection between strategic management and HRM. 


\section{References}

Argote, L., Ingram, P., Levine, J. M., \& Moreland, R. L. (2000). Knowledge transfer in organizations: Learning from the experience of others. Organizational Behavior \& Human Decision Processes, 82(1), 1-8.

Arthur, J. B. (1994). Effects of human resource systems on manufacturing performance and turnover. Academy of Management Journal, 37(3), 670.

Bae, J., \& Lawler, J. J. (2000). Organizational and HRM strategies in Krea: Impact on firm performance in an emerging economy. Academy of Management Journal, 43(3), 502.

Baird, L., \& Meshoulam, I. (1988). Managing two fits of strategic human resource management. Academy of Management Review, 13(1), 116.

Barney, J. (1991). Firm resources and sustained competitive advantage. Journal of Management, 17(1), 99.

Batt, R. (1999). Work organization, technology, and performance in customer service and sales. Industrial \& Labor Relations Review, 52(4), 539.

Becker, B. E., \& Huselid, M. A. (1998). High performance work systems and firm performance: A synthesis of research and managerial applications. Research in Personnel and Human Resources Management, 16, 53-101.

Becker, B., \& Gerhart, B. (1996). The impact of human resource management on organizational performance: Progress and prospects. Academy of Management Journal, 39(4), 779.

Beer, M., Spector, M., Lawrence, P. R., Mills, D. Q., \& Walton, R. E. (1984). Managing human assets. New York: Free Press.

Battacharya, M. \& Wright, P. (2005). Managing human assets in an uncertain world: Applying real options theory to HRM. International Journal of Human Resource Management $\underline{16}$, 929-948.

Boxall, P., \& Purcell, J. (2003). Strategy and human resource management. New York: Palgrave Macmillan.

Boxall, P. (1996) The strategic HRM debate and the resource-based view of the firm. Human Resource Management Journal, 6: 59-75.

Boxall, P. (1998). Achieving competitive advantage through human resource strategy: Towards a theory of industry dynamics. Human Resource Management Review, 8(3), 265.

Boxall, P., \& Purcell, J. (2000). Strategic human resource management: Where have we come from and where should we be going? International Journal of Management Reviews, 2(2), 183.

Brewster, C. (1999). Different paradigms in strategic HRM: Questions raised by comparative research. In P. Wright, L. Dyer, J. Boudreau \& G. Milkovich (Eds.), Research in personnel and human resource management: Strategic HRM in the 21st century (Supplement 4 ed.). Greenwich, CT: JAI Press.

Brewster, C., Sparrow, P., \& Harris, H. (2005). Towards a new model of globalizing HRM. International Journal of Human Resource Management, 16

Capelli, P. \& Singh, H. (1992). Integrating strategic human resources and strategic management. In D. Lewin, O.S. Mitchell, \& P.D. Sherer (Eds.) Research frontiers in industrial relations and human resources pp 165-192. Madison, WI: IRRA.

Collins, C. J., \& Clark, K. D. (2003). Strategic human resource practices, top management team social networks, and firm performance: The role of human resource practices in creating organizational competitive advantage. Academy of Management Journal, 46(6), 740-751.

d'Arcimoles, C. (1997). Human resource policies and company performance: A quantitative approach using longitudinal data. Organization Studies (Walter De Gruyter GmbH \& Co.KG.), 18(5), 857.

Delery, J. E. (1998). Issues of fit in strategic human resource management: Implications for research. Human Resource Management Review, 8(3), 289. 
Delery, J. E., \& Doty, D. H. (1996). Modes of theorizing in strategic human resource management: Tests of universalistic, contingency.. Academy of Management Journal, 39(4), 802.

Devanna, M. A., Fombrun, C., \& Tichy, N. (1981). Human resources management: A strategic perspective. Organizational Dynamics, 9(3), 51.

Dutta, S., Narasimhan, O., \& Rajiv, S. (2005). Conceptualizing and measuring capabilities: Methodology and empirical application. Strategic Management Journal, 26(3), 277-285.

Dyer, L. (1984). Studying human resource strategy. Industrial Relations, 23(2)

Dyer, L., \& Reeves, T. (1995). Human resource strategies and firm performance: What do we know and where do we need to go? International Journal of Human Resource Management, 6(3), 656.

Fiol, C. M., \& Lyles, M. A. (1985). Organizational learning. Academy of Management Review, 10(4), 803.

Fisher, S. R., \& White, M. A. (2000). Downsizing in a learning organization: Are there hidden costs? Academy of Management Review, 25(1), 244-251.

Grant, R. M. 1. (1996). Toward a knowledge-based theory of the firm. Strategic Management Journal, 17, 109.

Gratton, L., Hailey, V. H., \& Truss, C. (2000). Strategic human resource management. New York: Oxford University.

Guest, D. E. (2001). Human resource management: When research confronts theory. International Journal of Human Resource Management, 12(7), 1092-1106.

Guest, D. E., Michie, J., Conway, N., \& Sheehan, M. (2003). Human resource management and corporate performance in the UK. British Journal of Industrial Relations, 41(2), 291-314.

Hitt, M. A., Ireland, R. D., \& Hoskisson, R. E. (2005). Strategic management competitiveness and globalization (6th ed.). Mason, Ohio: Thompson South-Western.

Hitt, M. Bierman, L., Shimizu, K. \& Kochar, R. (2001). Direct and moderating effects of human capital on the strategy and performance in professional service firms: A resource-based perspective. Academy of Management Journal, 44, 13-28.

Huselid, M. A. (1995). The impact of human resource management practices on turnover, productivity, and corporate.. Academy of Management Journal, 38(3), 635.

Huselid, M. A., Jackson, S. E., \& Schuler, R. S. (1997). Technical and strategic human resources management effectiveness as determinants of firm performance. Academy of Management Journal, 40(1), 171.

Inkpen, A. C., \& Tsang, E. W. K. (2005). Social capital, networks, and knowledge transfer. Academy of Management Review, 30(1), 146-165.

Jackson, S. E., Schuler, R. S., \& Carlos Rivero, J. (1989). Organizational characteristics as predictors of personnel practices. Personnel Psychology, 42(4), 727-786.

Lee, J. \& Miller, D. (1999). People matter: Commitment to employees, strategy and performance in Korean firms. Strategic Management Journal, 20(6), 579.

Kinnie, N., Swart, J., \& Purcell, J. (2005). Influences on the choice of HR systems: The network organization perspective. International Journal of Human Resource Management, 16

Kogut, B., \& Zander, U. (1992). Knowledge of the firm, combinative capabilities, and the replication of technology. Organization Science: A Journal of the Institute of Management Sciences, 3(3), 383-397.

Lado, A. A., \& Wilson, M. C. (1994). Human resource systems and sustained competitive advantage: A competency-based perspective. Academy of Management Review, 19(4), 699-727.

Lahteenmäki, S., Storey, J., \& Vanhala, S. (1998). HRM and company performance: The use of measurement and the influence of economic cycles. Human Resource Management Journal, 8(2), 51-65. 
Lee, M. B., \& Chee, Y. (1996). Business strategy, participative human resource management and organizational performance: The case of south Korea. Asia Pacific Journal of Human Resources, 34, 77-94.

Lengnick-hall, C. A., \& Lengnick-hall, M. L. (1988). Strategic human resources management: A review of the literature and a proposed typology. Academy of Management Review, 13(3), 454.

Lepak, D. P., \& Snell, S. A. (1999). The human resource architecture: Toward a theory of human capital allocation and development. Academy of Management Review, 24: 31-48

Macduffie, J. P. (1995). Human resource bundles and manufacturing performance: Organizational logic and flexible.. Industrial \& Labor Relations Review, 48(2), 197.

Mahoney, J., \& Pandian, J. (1992). Resource-based view within the conversation of strategic management. Strategic Management Journal, 13: 363-380

McFadyen, M. A., \& Cannella Jr., A. A. (2004). Social capital and knowledge creation: Diminishing returns of the number and strength of exchange relationships. Academy of Management Journal, 47(5), 735-746.

McGrath, R. G. (1997). A real options logic for initiating technology positioning investments. Academy of Management Review, 22(4), 974-996.

Meyer, J. \&U Rowan, E. (1977). Institutionalize organizations: Formal structure as myth and ceremony. American Journal of Sociology, 83:340-363.

Miles, R. E., Snow, C. C., \& Meyer, A. D. (1978). Organizational strategy, structure, and process. Academy of Management Review, 3(3), 546.

Paauwe, J. (2004) HRM and Performance: Achieving Long Term Viability. Oxford: Oxford University Press.

Paauwe, J., \& Boselie, P. (2005). Best practices... in spite of performance: Just a matter of imitation? International Journal of Human Resource Management, 16(6): 987-1003.

Paauwe, J., \& Boselie, P. (2003). Challenging 'strategic HRM' and the relevance of the institutional setting. Human Resource Management Journal, 13(3), 56.

Peters, T. J., \& Waterman, R. (1982). In search of excellence. New York: Harper and Row.

Pfeffer, J. (1998). The human equation: Building profits by putting people first. Boston, MA: Harvard Business School Press.

Porter, M., E. (1985). Competitive advantage. New York: New York Free Press.

Porter, M. E. (1980). Competitive strategy. New York: New York Free Press.

Priem, R. \& Butler, J. (2001a) Is the resource-based "view" a useful perspective for strategic management research? Academy of Management Review, 26: 22-41.

Priem \& Butler, J. (2001b). Tautology in the resource-based view and the implications of externally determined resource value: Further comments. Academy of Management Review, 26: $57-67$.

Richard, O. (2001). Racial diversity, business strategy, and firm performance: A resource-based view. Academy of Management Journal, 43: 164-177.

Rodríguez, J. M., \& Ventura, J. (2003). Human resource management systems and organizational performance: An analysis of the Spanish manufacturing industry. International Journal of Human Resource Management, 14(7), 1206-1226.

Rogers, E. W., \& Wright, P. M. (1998). Measuring organizational performance in strategic human resource management: Problems, prospects, and performance information markets. Human Resource Management Review, 8(3), 311.

Schuler, R. S., \& Jackson, S. E. (1987). Linking competitive strategies with human resource management practices. Academy of Management Executive, 1(3), 207.

Snell, S. A., Shadur, M. A., \& Wright, P. M. (2001). Human resources strategy: The era of our ways. Blackwell Handbook of Strategic Management, , 627-649.

Teece, D. J., Pisano, G., \& Shuen, A. (1997). Dynamic capabilities and strategic management. Strategic Management Journal, 18(7), 509-533. 
Thompson, M., \& Heron, P. (2005). Management capability and high performance work organization. International Journal of Human Resource Management, 16

Trigeorgis, L. (1996). Real options: Managerial flexibility and strategy in resource allocation. Cambridge, MA: MIT Press.

Truss, C., \& Gratton, L. (1994). Strategic human resource management: A conceptual approach. International Journal of Human Resource Management, 5(3), 663.

Tyson, S. (1997). Human resource strategy: A process for managing the contribution of HRM to organizational performance. International Journal of Human Resource Management, 8(3), 277-290.

Walker, J. (1980). Human resource planning. New York: McGraw-Hill.

Wan, D., Ong, C. H., \& Kok, V. (2002). Strategic human resource management and organizational performance in Singapore. Compensation \& Benefits Review, 34(4), 33.

Wernerfelt, B. (1984). A resource-based view of the firm. Strategic Management Journal, 5(2), 171-180.

Wright, P. (1998). Strategy-HR Fit: Does it really matter? Human Resource Planning, 21(4), 56-57.

Wright, P. M., \& Gardner, T. M. (2003). Theoretical and empirical challenges in studying the HR practice - firm performance relationship. In D. Holman, T. D. Wall, C. Clegg, P. Sparrow \& A. Howard (Eds.), The new workplace: People technology, and organisation. Sussex, UK: Wiley.

Wright, P. \& Sherman, S. (1999). Failing to find fit in strategic human resource management: Theoretical and empirical problems. In Wright, P., Dyer, L., Boudreau, J., \& Milkovich, G. (Eds.). Research in Personnel and Human Resource Management (Supplement 4). pp. 5374. Greenwich, CT: JAI Press.

Wright, P. M., Dunford, B. B., \& Snell, S. A. (2001). Human resources and the resource-based view of the firm. Journal of Management, 27(6), 701.

Wright, P. M., Gardner, T. M., Moynihan, L. M., \& Allen, M. R. (2005). The relationship between hr practices and firm performance: Examining causal order. Personnel Psychology, 58(2), 409-446.

Wright, P. M., \& McMahan, G. C. (1992). Theoretical perspectives for strategic human resource management. Journal of Management, 18(2), 295.

Wright, P. M., McMahan, G. C., \& McWilliams, A. (1994). Human resources and sustained competitive advantage: A resource-based perspective. International Journal of Human Resource Management, 5(2), 301.

Wright, P. M., McMahan, G.C., \& Smart, D. L. (1995). Matches between human resources and strategy among NCAA basketball teams. Academy of Management Journal, 38(4), 1052.

Wright, P. M., \& Snell, S. A. (1998). Toward a unifying framework for exploring fit and flexibility in strategic human resource.. Academy of Management Review, 23(4), 756.

Wright, P. M., \& Snell, S. A. (1991). Toward an integrative view of strategic human resource management. Human Resource Management Review, 1(3), 203.

Youndt, M. A., Snell, S. A., Dean, J. W., Jr, \& Lepak, D. P. (1996). Human resource management, manufacturing strategy, and firm performance. Academy of Management Journal, 39(4), 836. 